\title{
Streptomyces bohaiensis sp. nov., a novel actinomycete isolated from Scomberomorus niphonius in the Bohai Sea
}

\author{
Hua-Qi Pan ${ }^{1,5}$, Juan Cheng ${ }^{2,5}$, Dao-Feng Zhang ${ }^{2}$, Su-Ya Yu ${ }^{1}$, Thi-Nhan Khieu ${ }^{2,3}$, Chu Ky Son ${ }^{3}$, \\ Zhao Jiang ${ }^{2}$, Jiang-Chun $\mathrm{Hu}^{1}$ and Wen-Jun $\mathrm{Li}^{2,4}$
}

A novel actinomycete strain, designated $11 \mathrm{A07}^{\top}$, was isolated from young Scomberomorus niphonius in the Bohai Sea. Basic local alignment search tool analyses showed that this isolate had the highest 16S rRNA gene sequence similarity of $97.41 \%$ with Streptomyces rimosus subsp. paromomycinus DSM $41429^{\top}$. Phylogenetic tree revealed that strain $11 \mathrm{A07}{ }^{\mathrm{T}}$ formed a distinct lineage clustered with Streptomyces panacagri Gsoil $519^{\top}$, Streptomyces sodiiphilus YIM $80305^{\top}$ and Streptomyces albus subsp. albus NRRL B-2365 ${ }^{\top}$ having similarities of $97.30 \%, 97.10 \%$ and $96.83 \%$, respectively. Multilocus sequence analysis further demonstrated that the new isolate was different from the selected representatives of Streptomyces as a separate phylogenetic line. Strain $11 \mathrm{AO}^{\top}$ produced straight or rectiflexibile spore chains with smooth surface, white aerial mycelia and brown diffusible pigments on international streptomyces project 2 medium. Maximum tolerated $\mathrm{NaCl}$ concentration for growth was $11.0 \%$. Whole-cell sugars were mannose, ribose, glucose, galactose and xylose. The predominant menaquinones were MK-9 $\left(\mathrm{H}_{2}\right)$, MK-9 $\left(\mathrm{H}_{4}\right)$ and MK-9 $\left(\mathrm{H}_{6}\right)$. The fatty-acid profile contained iso- $\mathrm{C}_{16: 0}, \mathrm{C}_{18: 0}$ 10-methyl (tuberculostearic acid) and anteiso- $\mathrm{C}_{17: 0}$ as the major compositions. The polar lipids consisted of diphosphatidylglycerol, phosphatidylethanolamine, phosphatidylinositol, phosphatidylinositol mannoside and an unknown phospholipid. The $\mathrm{G}+\mathrm{C}$ content of the genomic DNA was $71.4 \mathrm{~mol} \%$. These morphological, phenotypic and chemotaxonomic properties showed that strain $11 \mathrm{AO} 7^{\top}$ could be readily distinguished from the most closely related members of the genus Streptomyces. Thus, based on the polyphasic taxonomic data, strain $11 \mathrm{A07}^{\top}\left(=\mathrm{JCM} 19630^{\top}=\mathrm{CCTCC}\right.$ AA $\left.2013020^{\top}=\mathrm{KCTC} 29263^{\top}\right)$ represents a novel species within the genus Streptomyces, for which the name Streptomyces bohaiensis sp. nov. is proposed.

The Journal of Antibiotics (2015) 68, 246-252; doi:10.1038/ja.2014.137; published online 1 October 2014

\section{INTRODUCTION}

The genus Streptomyces was proposed by Waksman and Henrici ${ }^{1}$ to encompass an aerobic, spore-forming group of actinomycetes. The Streptomyces is widely distributed in nature and encompasses more than 630 species. $^{2}$ Many members of this genus are a source of a broad range of novel bioactive compounds. According to statistics, actinomycete sources account for about 53\% of all microbial bioactive secondary metabolites with 7600 of these compounds (75\%) being produced by Streptomyces. ${ }^{3}$ However, it is becoming increasingly difficult to find new leading compounds from common actinomycetes and leads to the costly rediscovery of known compounds. ${ }^{4}$ On the other hand, the demand of anticancer and anti-infectious drug discovery is growing. Hence, the investigation for new actinomycete resource is an important element in drug discovery.
Nowadays, marine actinomycetes have been widely explored for potential source of novel compounds as the environmental conditions of the sea are entirely different from the terrestrial conditions. ${ }^{5,6}$ Although new actinomycetes and antibiotics have been discovered from sponges, algae, mangrove plants and other marine animals and plants, ${ }^{7,8}$ the full suite of actinomycete occupying some special ecological niches have not been fully investigated. Therefore our work was focused on the isolation of actinomycetes from a wide variety of marine animals of the Bohai Sea, such as blue mussel, jellyfish, shrimp, fish, crabs, starfish, sea urchins etc., and on screening for their ability to produce antimicrobials. During our continuous screening for new antibiotics, a putatively novel Streptomyces strain $11 \mathrm{~A} 07^{\mathrm{T}}$ from a fish in the Bohai Sea had the genetic potential to produce secondary metabolites related to both polyketides and nonribosomal peptides,

${ }^{1}$ Institute of Applied Ecology, Chinese Academy of Sciences, Shenyang, China; ${ }^{2}$ Key Laboratory of Microbial Diversity in Southwest China, Ministry of Education, Yunnan Institute of Microbiology, Yunnan University, Kunming, China; ${ }^{3}$ School of Biotechnology and Food Technology, Hanoi University of Science and Technology, Hanoi, Vietnam and ${ }^{4}$ State Key Laboratory of Biocontrol, Key Laboratory of Biodiversity Dynamics and Conservation of Guangdong Higher Education Institutes, College of Ecology and Evolution, Sun Yat-Sen University, Guangzhou, China

${ }^{5}$ These authors contributed equally to this work.

Correspondence: Professor W-J Li, Yunnan Institute of Microbiology, Yunnan University, Kunming, Yunnan 650091, China

E-mail: wjli@ynu.edu.cn

or Professor J-C Hu, Institute of Applied Ecology, Chinese Academy of Sciences, Shenyang, China

E-mail: hujc@iae.ac.cn

Received 5 April 2014; revised 20 August 2014; accepted 2 September 2014; published online 1 October 2014 
as well as showed potent antimicrobial activities. ${ }^{9}$ In this study, we report the classification and identification of this new isolate based on polyphasic taxonomy. Further, the name Streptomyces bohaiensis sp. nov. $11 \mathrm{~A} 07^{\mathrm{T}}$ is proposed as a novel Streptomyces species.

\section{MATERIALS AND METHODS}

\section{Strain and maintenance condition}

The young Scomberomorus niphonius (long, slender, laterally flattened, pelagic fish with longitudinal dark spots on the sides and $\sim 15 \mathrm{~cm}$ in fork length) was collected from the Bohai Sea, located in eastern Liaoning Peninsula in northern China $\left(39^{\circ} 20^{\prime} \mathrm{N}, 122^{\circ} 17^{\prime} \mathrm{E}\right)$. The specimen was rinsed five times with sterile artificial seawater to remove any transient and loosely attached microorganisms from the surface of the $S$. niphonius. $1 \mathrm{~cm}^{3}$ sections of specimen tissue were excised with a sterile scalpel and ground with a sterilized mortar and pestle. Then tissue homogenates were inoculated on oatmeal agar international streptomyces project (ISP 3) plates using a standard dilution plating method, containing nalidixic acid $\left(25 \mathrm{mg}^{-1}\right)$ and cycloheximide $\left(50 \mathrm{mg} \mathrm{l}^{-1}\right.$ ) to inhibit growth of bacteria and fungi. After incubation at $28^{\circ} \mathrm{C}$ for 3 weeks, an isolate designated $11 \mathrm{~A} 07^{\mathrm{T}}$ was picked. The strain was maintained on plates of modified Gauze's synthetic medium No.1 (soluble starch $20.0 \mathrm{~g} ; \mathrm{KNO}_{3} 1.0 \mathrm{~g} ; \mathrm{MgSO}_{4}$. $7 \mathrm{H}_{2} \mathrm{O} 0.5 \mathrm{~g} ; \mathrm{K}_{2} \mathrm{HPO}_{4} 0.5 \mathrm{~g} ; \mathrm{FeSO}_{4} \cdot 7 \mathrm{H}_{2} \mathrm{O} 10.0 \mathrm{mg}$; agar $15.0 \mathrm{~g}$; artificial sea water $1.0 \mathrm{l}$; adjust $\mathrm{pH} 7.0$ ) at $4^{\circ} \mathrm{C}$ and as suspensions of spores or mycelia fragments in glycerol $\left(20 \%\right.$, v/v) at $-80^{\circ} \mathrm{C}$.

\section{Phenotypic characterization}

Strain $11 \mathrm{~A} 07^{\mathrm{T}}$ was cultured for 14 days at $28^{\circ} \mathrm{C}$ on tryptic soy agar (TSA) using the coverslip technique. ${ }^{10}$ Morphological properties were observed by a light microscope (BH-2; Olympus, Tokyo, Japan) and a scanning electron microscope (Quanta200; FEI, Hillsboro, OR, USA). ${ }^{11}$ Cultural properties were determined using standard ISP media, ${ }^{12}$ Czapek's agar, nutrient agar (Difco, Sparks, MD, USA) and potato dextrose agar (Difco) after incubation at $28^{\circ} \mathrm{C}$ for 14 days. Colors of the aerial, substrate mycelia and diffusible pigments were determined using color chips from the ISCC-NBS color charts.
Growth at various $\mathrm{NaCl}$ concentrations $(0,0.5,1.0,2.0,3.0,4.0,5.0$, $6.0,7.0,10.0,11.0,12.0,15.0 \%, \mathrm{w} / \mathrm{v})$ and different temperatures $\left(4,10,28,37,45,50^{\circ} \mathrm{C}\right)$ was examined by growing the strain on TSA medium as the basal medium. Growth at different $\mathrm{pH}$ values (4.011.0 , at intervals of $1.0 \mathrm{pH}$ unit) was examined on modified TSA medium using the buffer system described by $\mathrm{Xu}$ et al. ${ }^{13}$ Oxidase activity was determined by the oxidation of tetramethyl- $p$-phenylenediamine. Catalase activity was determined by $3 \% \mathrm{H}_{2} \mathrm{O}_{2}$, and gas production was identified as a positive reaction. Hydrolysis of starch, gelatin, Tweens 20, 40, 60 and 80, milk coagulation and peptonization were carried out according to methods described by Tindall et al. ${ }^{14}$ Nitrate reduction and $\mathrm{H}_{2} \mathrm{~S}$ production were determined using conventional procedures. ${ }^{14,15}$ Carbon-source utilization tests were performed according to the methods described by Shirling and Gottlieb ${ }^{12}$ and Athalye et al. ${ }^{16}$ using modified basal medium ${ }^{17}$ supplemented with $0.05 \%$ yeast extract.

\section{Chemotaxonomic characterization}

The biomass used for analyses of cellular fatty acids was obtained from cultures grown in tryptic soy broth for 7 days in flasks shaken at 180 r.p.m. at $28^{\circ} \mathrm{C}$. The cells were harvested by centrifugation at 4500 r.p.m. for $10 \mathrm{~min}$ and washed twice with sterile distilled water. Cellular fatty acids were extracted, methylated and analyzed using the Sherlock Microbial Identification System according to the method of Sasser ${ }^{18}$ as the manufacturer's instructions. Fatty acids were then analyzed by GC (Agilent Technologies 7890A GC System, Wilmington, DE, USA) using the Microbial Identification software package (Sherlock Version 6.1; Sherlock Microbial Identification System database TSBA6). The diaminopimelic acid isomer was identified by TLC. ${ }^{19}$ The whole-cell sugars were separated by HPLC after precolumn derivatization with 1-phenyl-3-methyl-5-pyrazolone..$^{20}$ Menaquinones were extracted ${ }^{21}$ and determined by HPLC. ${ }^{22}$ Polar lipids were extracted and examined according to published procedures. ${ }^{23,24}$

\section{Molecular characterization}

Genomic DNA isolation, PCR amplification of $16 \mathrm{~S}$ rRNA gene, cloning and sequencing were performed with conventional

Table 1 House-keeping gene sequences of the new isolate and those related Streptomyces strains used in the present study

\begin{tabular}{|c|c|c|c|c|c|c|}
\hline Species & Strain & $\operatorname{atpD}$ & gyr $B$ & $\operatorname{rec} A$ & $r p o B$ & $\operatorname{trp} B$ \\
\hline Streptomyces bohaiensis & $11 \mathrm{~A} 07^{\top}$ & KM349180 & KM349181 & KM349182 & KM349183 & KM349184 \\
\hline S. rimosus subsp. paromomycinus & AS $4.1760^{\top}=$ DSM $41429^{\top}$ & FJ406154 & FJ406210 & FJ406266 & FJ406322 & FJ406377 \\
\hline S. chrestomyceticus & $\mathrm{JCM} 4735^{\top}=\mathrm{DSM} 40545^{\top}$ & FJ406149 & FJ406205 & FJ406261 & FJ406317 & FJ406372 \\
\hline S. albofaciens & JCM $4342^{\top}$ & FJ406148 & FJ406204 & FJ406260 & FJ406316 & FJ406371 \\
\hline S. albospinus & AS $4.1628^{\top}=N B R C 13846^{\top}$ & FJ406146 & FJ406202 & FJ406258 & FJ406314 & FJ406369 \\
\hline S. javensis & DSM $41764^{\top}=$ NBRC $100777^{\top}$ & FJ406177 & FJ406233 & FJ406289 & FJ406344 & FJ406400 \\
\hline S. yogyakartensis & DSM $41766^{\top}=$ NBRC $100779^{\top}$ & FJ406178 & FJ406234 & FJ406290 & FJ406345 & FJ406401 \\
\hline S. violaceusniger & AS $4.1423^{\top}=$ NBRC $13459^{\top}$ & FJ406139 & FJ406195 & FJ406251 & FJ406307 & FJ406362 \\
\hline S. albus & AS $4.1845^{\top}$ & EF031314 & EF055001 & EF055056 & EF055111 & EF055166 \\
\hline S. lydicus & AS $4.1412^{\top}=$ NBRC $13058^{\top}$ & FJ406136 & FJ406192 & FJ406248 & FJ406304 & FJ406359 \\
\hline S. rhizosphaericus & DSM $41760^{\top}=$ NBRC $100778^{\top}$ & FJ406175 & FJ406231 & FJ406287 & FJ406342 & FJ406398 \\
\hline S. endus & AS $4.1377^{\top}=N R R L 2339^{\top}$ & FJ406134 & FJ406190 & FJ406246 & FJ406302 & FJ406357 \\
\hline S. catenulae & AS $4.1701^{\top}=$ ISP $5258^{\top}$ & FJ406152 & FJ406208 & FJ406264 & FJ406320 & FJ406375 \\
\hline S. sioyaensis & AS $4.1306^{\top}=$ NRRL B-5408 & FJ406132 & FJ406188 & FJ406244 & FJ406300 & FJ406355 \\
\hline S. angustmyceticus & CGMCC $4.1918^{\top}=$ NBRC $3934^{\top}$ & HQ244475 & HQ244480 & HQ244485 & HQ244490 & HQ244495 \\
\hline S. hygroscopicus subsp. hygroscopicus & CGMCC $4.1527^{\top}=N R R L 2387^{\top}$ & HQ244473 & HQ244478 & HQ244483 & HQ244488 & HQ244493 \\
\hline S. sclerotialus & DSM $43032^{\top}$ & FJ406181 & FJ406237 & FJ406293 & FJ406348 & FJ406404 \\
\hline S. demainii & DSM $41600^{\top}=N R R L B-1478^{\top}$ & FJ406182 & FJ406238 & FJ406294 & FJ406349 & FJ406405 \\
\hline S. nigrescens & AS $4.1410^{\top}=\mathrm{NBRC} 12894^{\top}$ & FJ406135 & FJ406191 & FJ406247 & FJ406303 & FJ406358 \\
\hline S. chattanoogensis & DSM $40002^{\top}$ & FJ406138 & FJ406194 & FJ406250 & FJ406306 & FJ406361 \\
\hline
\end{tabular}


methods. ${ }^{25}$ Sequence analysis of $16 \mathrm{~S}$ rRNA gene was performed using Basic Local Alignment Search Tool for Nucleotides (BLASTN). The $16 \mathrm{~S}$ rRNA gene sequence of strain $11 \mathrm{~A} 07^{\mathrm{T}}$ was compared with sequences from EzBioCloud using basic local alignment search tool (http://eztaxon-e.ezbiocloud.net/). ${ }^{26}$ Multilocus sequence analysis was based on five house-keeping genes atpD (ATP synthase F1, beta subunit), gyrB (DNA gyrase B subunit), recA (recombinase A), rpoB (RNA polymerase beta subunit) and $\operatorname{trp} B$ (tryptophan synthetase, beta subunit) using the primers and protocols described previously. ${ }^{27}$ Sequence data for the five house-keeping loci for each strain were deposited in GenBank with the accession numbers shown in Table 1. All these gene sequences were aligned with corresponding sequences (retrieved from the GenBank/EMBL/DDBJ database) using CLUSTAL X1.83. ${ }^{28}$ The $16 \mathrm{~S}$ rRNA gene and five house-keeping gene sequenceconcatenated phylogenetic trees were constructed by the NeighborJoining, ${ }^{29}$ Maximum Parsimony ${ }^{30}$ and Maximum-Likelihood ${ }^{31}$ tree-making algorithms by using the software packages MEGA version 5.0. ${ }^{32}$ Concatenated sequences of all five protein-coding loci were joined head-to-tail in-frame. Evolutionary distance matrices were generated according to the Kimura's two parameter model. ${ }^{33}$ The topologies of the resultant trees were evaluated by bootstrap analysis with 1000 replicates. ${ }^{34}$ The $\mathrm{G}+\mathrm{C}$ content of genomic DNA prepared by the method of Marmur ${ }^{35}$ was determined using the HPLC method as described by Mesbah et al. ${ }^{36}$

\section{RESULTS AND DISCUSSION}

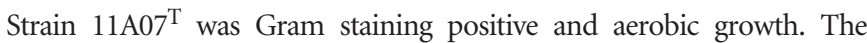
strain produced extensively branched substrate mycelia and aerial hyphae, but not fragmented. Scanning electron microscopy revealed straight or rectiflexibile chains of smooth surfaced spores were borne on aerial hyphae. Spore chains were generally straight and very long containing $>50$ spores (Figure 1). These characteristics supported strain $11 \mathrm{~A} 07^{\mathrm{T}}$ belonging to the genus Streptomyces. ${ }^{37}$ Strain $11 \mathrm{~A} 07^{\mathrm{T}}$ showed abundant growth on ISP 2, ISP 3, ISP 5, TSA, Czapek solution agar and Nutrient agar, but moderate growth on ISP 4 and poor growth on potato dextrose agar. White aerial mycelium was observed on these media, but variety of substrate mycelium color was displayed on different media. Brown diffusible pigments were detected on ISP 2 and Czapek solution agar (Table 2). The growth temperature for strain $11 \mathrm{~A} 07^{\mathrm{T}}$ was $15-40^{\circ} \mathrm{C}$ (optimum $28^{\circ} \mathrm{C}$ ). The strain $11 \mathrm{~A} 07^{\mathrm{T}}$ grew at $\mathrm{pH}$ 6-10 (optimum 8-9) and 0-11\% (w/v) $\mathrm{NaCl}$ (optimum 1). It could utilize glucose, L-rhamnose, D-galactose, inositol, raffinose, D-mannitol, salicin, sorbitol, sucrose and sodium citrate as sole carbon source for growth, but not L-arabinose, D-fructose and D-xylose. Other physiological characteristics are given in Table 3 and in the species description.

$L L$-diaminopimelic acid was detected in the peptidoglycan of strain $11 \mathrm{~A} 07^{\mathrm{T}}$. The cell wall sugars were mannose, ribose, glucose, galactose and xylose. The predominant menaquinones were found with MK-9 $\left(\mathrm{H}_{2}\right)$ 12.7\%, MK-9 $\left(\mathrm{H}_{4}\right) 60.3 \%$ and MK-9 $\left(\mathrm{H}_{6}\right) 25.0 \%$. The fatty-acid profile contained iso- $\mathrm{C}_{16: 0}(37.5 \%), \mathrm{C}_{18: 0}$ 10-methyl, tuberculostearic acid $(20.0 \%)$ and anteiso- $\mathrm{C}_{17: 0}(11.8 \%)$ as the major compositions (Supplementary Table S1). The polar lipids identified were diphosphatidylglycerol, phosphatidylethanolamine, phosphatidylinositol, phosphatidylinositol mannoside and an unknown phospholipid (Figure 2). These characteristics were consistent with those of genus Streptomyces.

The DNA G+C content of the genomic DNA of this strain was $71.4 \mathrm{~mol} \%$. An almost complete $16 \mathrm{~S}$ rRNA gene sequence (1520 bp) was obtained for isolate $11 \mathrm{~A} 07^{\mathrm{T}}$. The $16 \mathrm{~S}$ rRNA gene sequence of strain $11 \mathrm{~A} 07^{\mathrm{T}}$ was submitted in the GenBank Database under the accession number KF682221. Sequence analysis showed that 16S rRNA gene sequence of strain $11 \mathrm{~A} 07^{\mathrm{T}}$ to be most similar to those of Streptomyces rimosus subsp. paromomycinus DSM 41429 ${ }^{\mathrm{T}}$, Streptomyces chrestomyceticus DSM $40545^{\mathrm{T}}$, and Streptomyces panacagri Gsoil $519^{\mathrm{T}}$, with sequence identities of $97.41 \%, 97.40 \%$ and $97.30 \%$, respectively. Further phylogenetic analyses revealed that strain $11 \mathrm{~A} 07^{\mathrm{T}}$ formed a distinct branch separate from other representatives of the genus Streptomyces and most closely related with $S$. panacagri Gsoil $519^{\mathrm{T}}$ (similarity 97.30\%), Streptomyces albus subsp. albus NRRL B-2365 (similarity 97.10\%) and Streptomyces sodiiphilus YIM $80305^{\mathrm{T}}$ (similarity 96.83\%; Figure 3). Three phylogenetic tree showed that strain $11 \mathrm{~A} 07^{\mathrm{T}}$ forms a cluster with three of the above species, with the exception of $S$. sodiiphilus YIM $80305^{\mathrm{T}}$ by maximum-likelihood algorithm (Supplementary Figures S1 and S2). However, this relationship is not supported by significant bootstrap values nor by the stability. Stackebrandt and Ebers ${ }^{38}$ demonstrated that strains showing $<98.5 \% 16$ S rRNA gene sequence similarity presented DNA reassociation values always $<70 \%$. And further, Kim et al. ${ }^{39}$ suggested that $98.65 \%$ 16S rRNA gene sequence similarity can be used as the threshold for differentiating two species. In view of the lower $16 \mathrm{~S}$ rRNA gene sequence similarity values of strains $S$. panacagri Gsoil $519^{\mathrm{T}}$, S. sodiiphilus YIM $80305^{\mathrm{T}}$, S. albus subsp. albus NRRL B- $2365^{\mathrm{T}}$ and other close relatives (similarities $\leqslant 97.41 \%$ ), and the distinct phylogenetic positions of these strains, DNA-DNA hybridizations were not investigated in this study.
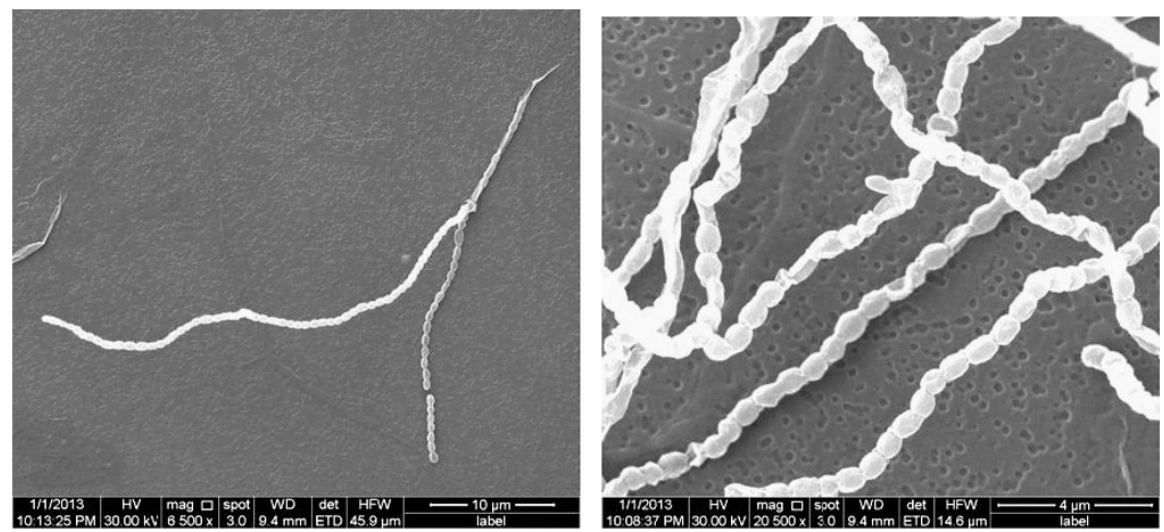

Figure 1 Scanning electron micrographs of spore chains of strain $11 \mathrm{AO}^{\top}$ after incubation at $28^{\circ} \mathrm{C}$ for 14 days on TSA medium. (a) Bar $10 \mu \mathrm{m}$; (b) $\operatorname{Bar} 4 \mu \mathrm{m}$. 
Table 2 Growth and cultural characteristics of strain $11 \mathrm{~A}^{\mathrm{T}} 7^{\mathrm{T}}$ on different growth media after incubation for 2 weeks at $28^{\circ} \mathrm{C}$

\begin{tabular}{lcccc}
\hline Medium & Growth & Aerial mycelium & Substrate mycelium \\
\hline Yeast extract-malt extract agar (ISP 2) & Good & White & Vivid yellow pink \\
Oatmeal agar (ISP 3) & Good & White & Blackish red & Brown \\
Inorganic salts-starch agar (ISP 4) & Moderate & White & None \\
Glycerol-asparagine agar (ISP 5) & Good & White & Slight yellow \\
Czapek solution agar (Difco) & Good & White & Vivid yellow pink & None \\
Nutrient agar (Difco) & Good & White & Violet & Nown \\
Tryptic soy agar (Difco) & Good & White & Nodium gray \\
Potato dextrose agar (Difco) & Poor & White & None \\
\hline
\end{tabular}

Table 3 Differential phenotypic and chemotaxonomic characteristics of strain 11A07A ${ }^{\top}$, and its closest phylogenetic neighbors Streptomyces

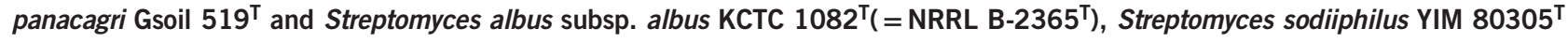

\begin{tabular}{|c|c|c|c|c|}
\hline Characteristic & $11 A O 7^{\top}$ & Gsoil $519^{T}$ & KCTC $1082^{T}$ & YIM $80305^{T}$ \\
\hline \multicolumn{5}{|l|}{ Morphology } \\
\hline Spore chains & Straight or Rectiflexibiles & Rectiflexibiles & Spirales & Rectiflexibiles \\
\hline Spore color & White & Mustard & White/yellow & White/gray \\
\hline Diffusible pigment on ISP 2 & Brown & None & None & None \\
\hline Gelatin liquefaction & - & + & + & + \\
\hline Nitrate reducase & + & - & + & + \\
\hline \multicolumn{5}{|l|}{ Utilization as sole nitrogen source } \\
\hline D-Galactose & w & + & - & - \\
\hline D-Fructose & - & + & - & - \\
\hline Inositol & + & + & + & - \\
\hline Raffinose & + & - & - & - \\
\hline Sucrose & + & + & + & - \\
\hline Whole-cell sugars & Man, Rib, Glu, Gal, Xyl & Rib, Xyl, Man, Glu & ND & Gal, Glu \\
\hline Predominant menaquinones (>10\%) & MK- $9\left(\mathrm{H}_{2,4,6}\right)$ & MK-9( $\left.\mathrm{H}_{6,8}\right)$ & ND & MK- $9\left(\mathrm{H}_{4,6,8}\right)$ \\
\hline Diagnostic phospholipids & DPG,PE, PI, PIM, PL & DPG, PE, PIM & ND & $P E$ \\
\hline Major fatty acids ( > 10\%) & $\mathrm{C}_{18: 0}, \mathrm{i}-\mathrm{C}_{16: 0}$, ai- $\mathrm{C}_{17: 0}, 10-\mathrm{m}-\mathrm{C}_{18: 0}$ & $\mathrm{C}_{16: 0}, \mathrm{i}-\mathrm{C}_{15: 0}, \mathrm{i}-\mathrm{C}_{17: 0}$, ai- $\mathrm{C}_{15: 0}$, ai- $\mathrm{C}_{17: 0}$ & $C_{18: 0}, C_{20: 0}$, ai- $C_{15: 0}$ & $\mathrm{i}-\mathrm{C}_{16: 0}$, ai- $\mathrm{C}_{15: 0}$, ai- $\mathrm{C}_{17: 0}$, \\
\hline
\end{tabular}

Abbreviations: +, Positive; -, negative; ai, anteiso; DPG, diphosphatidylglycerol; Gal, galactose; GL, glycolipids; Glu, glucose; i, iso; m, methyl; Man, mannose; ND, no data available; PC, phosphatidylcholine; PG, phosphatidylglycerol; PI, phosphatidylinositol; PIM, phosphatidylinositol mannoside; PL, phospholipids; PME, phosphatidylmethylethanolamine; PS, phosphatidylserine;
Rib, ribose; Xyl, xylose; TBSA, tuberculostearic acid; w, weakly positive.

Data were taken from Cui et al. ${ }^{41}$ and Li et al..$^{42}$

The strain $11 \mathrm{~A} 07^{\mathrm{T}}$ was further characterized by partial sequencing of $\operatorname{atpD}(981 \mathrm{nt}), \operatorname{gyrB}(891 \mathrm{nt}), \operatorname{rec} A(911 \mathrm{nt}), \operatorname{rpoB}(994 \mathrm{nt})$ and $\operatorname{trp} B$ (735 nt). The phylogenetic trees based on concatenated sequences (2511 bp) of atpD (position 101-595), gyrB (position 19-423), recA (position 109-612), rpoB (position 270-807) and $\operatorname{trpB}$ (position 45611) trimmed sequences unambiguously demonstrated that the isolate constituted a separate phylogenetic line within other closely related species of the genus Streptomyces (Figure 4, Supplementary Figures S3 and S4). As well as multilocus sequence analysis evolutionary distances were greater than the species-definitive multilocus sequence analysis distance $(0.007)^{40}$ with all of the phylogenetically near species as shown in Supplementary Table S2. These evidences supported the proposal that this strain represents a new species in the genus Streptomyces.

Moreover, strain $11 \mathrm{~A} 07^{\mathrm{T}}$ could utilize raffinose as sole carbon source and produce brown diffusible pigments on ISP 2 medium, but could not hydrolyze gelatin. All of these properties could distinguish the strain $11 \mathrm{~A} 07^{\mathrm{T}}$ from each of the three most closely related species. Other differences in phenotypic characteristics, which were summarized in Table 3, support strain $11 \mathrm{~A} 07^{\mathrm{T}}$ as a novel species. In view of the combination of morphological, physiological and phylogenetic data discussed above, it is evident that strain $11 \mathrm{~A} 07^{\mathrm{T}}$ forms a novel taxon within the genus Streptomyces. Therefore, it is proposed that this organism should be recognized as a novel species of the genus Streptomyces, for which the name Streptomyces bohaiensis sp. nov. is proposed.

\section{Description of $S$. bohaiensis sp. nov.}

S. bohaiensis [bo.hai.en'sis. N.L. masc. adj. bohaiensis of or pertaining to Bohai Sea, where the type strain was isolated]: Gram staining positive and aerobic actinomycete that forms extensively branched substrate 


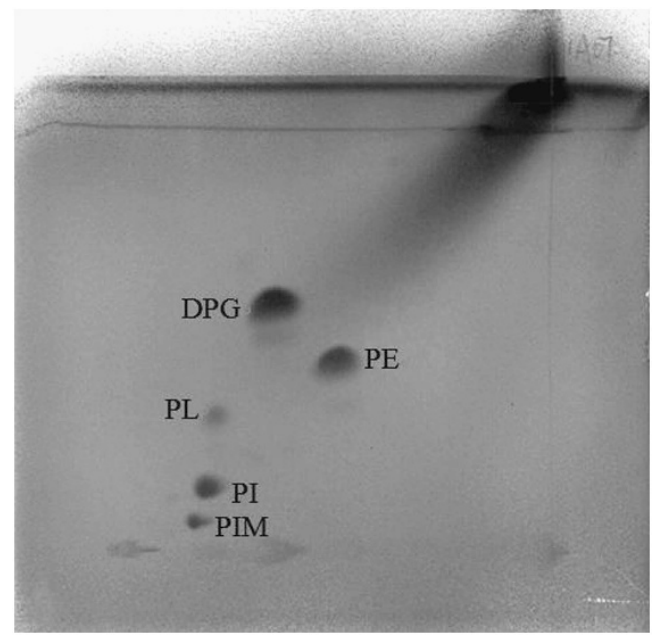

Figure 2 The polar lipid profiles of stains $11 A 07^{\top}$ stained with molybdophosphoric acid after separation by two-dimensional TLC. DPG, diphosphatidylglycerol; PE, phosphatidylethanolamine; PI, phosphatidylinositol; PIM, phosphatidylinositol mannoside; PL, unknown phospholipid. A full color version of this figure is available at The Journal of Antibiotics journal online. mycelia and aerial hyphae that carry straight or rectiflexibile spore chains containing $>50$ smooth spores. Grows well on ISP 2, ISP 3, ISP 5, TSA, Czapek solution agar and nutrient agar. The color of the aerial mycelium is white and the substrate mycelium has different colors on different media. Brown diffusible pigments are produced on ISP 2 and Czapek solution agar. Growth occurs in the presence of $11 \%$ $\mathrm{NaCl}(\mathrm{w} / \mathrm{v})$, temperature $15-40^{\circ} \mathrm{C}$ and $\mathrm{pH}$ value $6-10$, optimum at $1 \% \mathrm{NaCl}, 28^{\circ} \mathrm{C}, \mathrm{pH} 8-9$, respectively. Glucose, inositol, raffinose, Lrhamnose, D-galactose, D-mannitol, salicin, sorbitol, sucrose and sodium citrate are utilized as sole carbon source, but not L-arabinose, D-fructose and D-xylose. It can utilize L-valine, L-lysine, L-phenylalanine, L-histidine and L-alanine as sole nitrogen, but not L-methionine and glycine. Test for nitrate reductase is positive. Amylase and catalase activities are produced, but oxidase is not. $\mathrm{H}_{2} \mathrm{~S}$ production, gelatin liquefaction, milk coagulation and peptonization are negative. Tweens 40, 60 and 80 are hydrolyzed, but Tween 20 is not. Cell wall contains LL-diaminopimelic acid. Mannose, ribose, glucose, galactose and xylose are whole-cell sugars. The predominant menaquinones are MK-9 $\left(\mathrm{H}_{2}\right)$, MK-9 $\left(\mathrm{H}_{4}\right)$ and MK-9 $\left(\mathrm{H}_{6}\right)$. The fatty-acid profile contains iso- $\mathrm{C}_{16: 0}, \mathrm{C}_{18: 0}$ 10-methyl, tuberculostearic acid and anteiso- $\mathrm{C}_{17: 0}$ as the major components. The polar lipids consist of

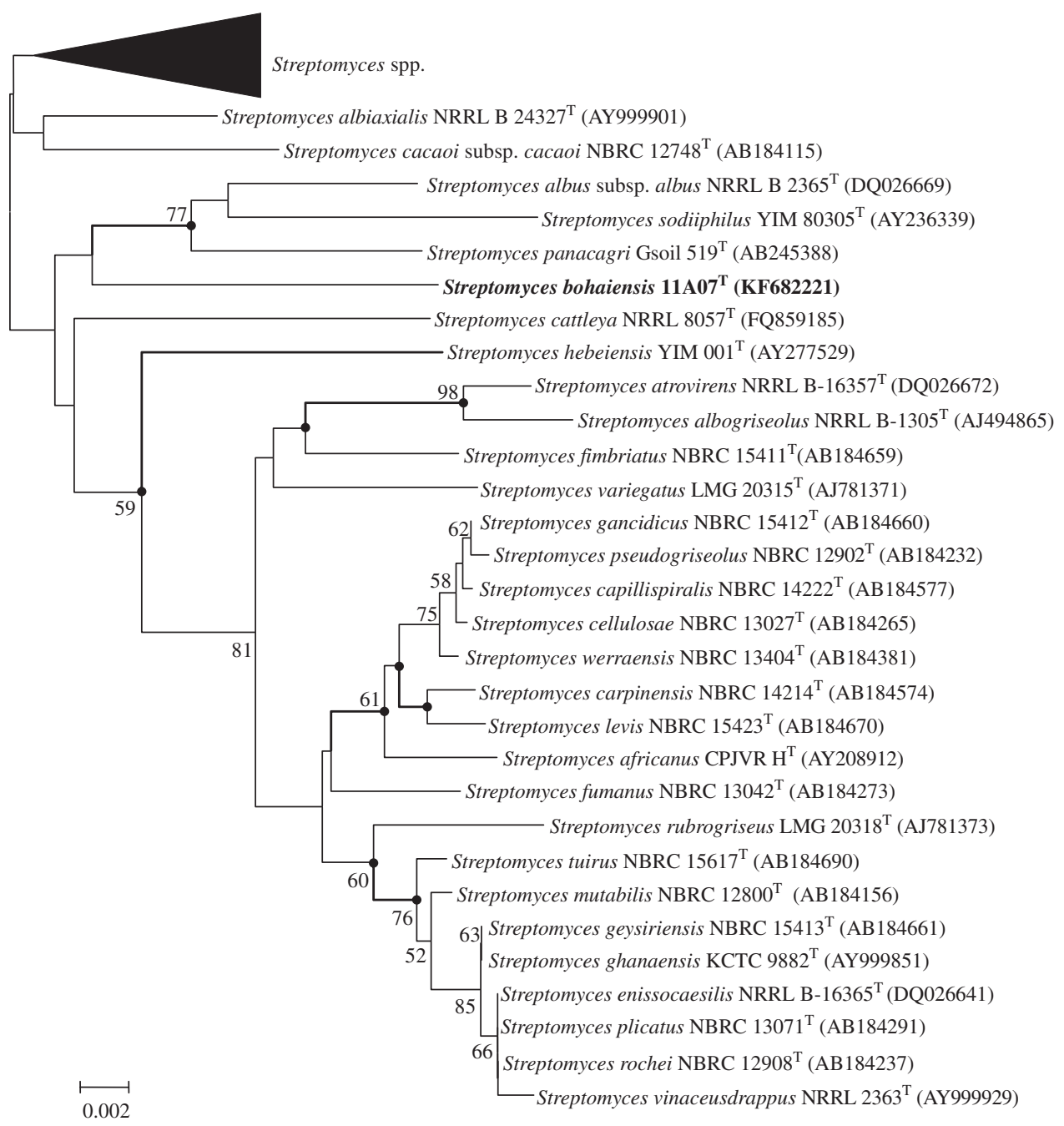

Figure 3 Neighbor-joining phylogenetic tree based on 16S rRNA gene sequences showing the position of strain $11 \mathrm{AO}^{\top}$ in the genus Strepomyces. Filled circles indicate branches that were also recovered using the maximum parsimony and maximum-likelihood trees. Bootstrap values (expressed as percentages of 1000 replications) of above $50 \%$ are shown at the branch points. Bar, 0.002 sequence divergence. 


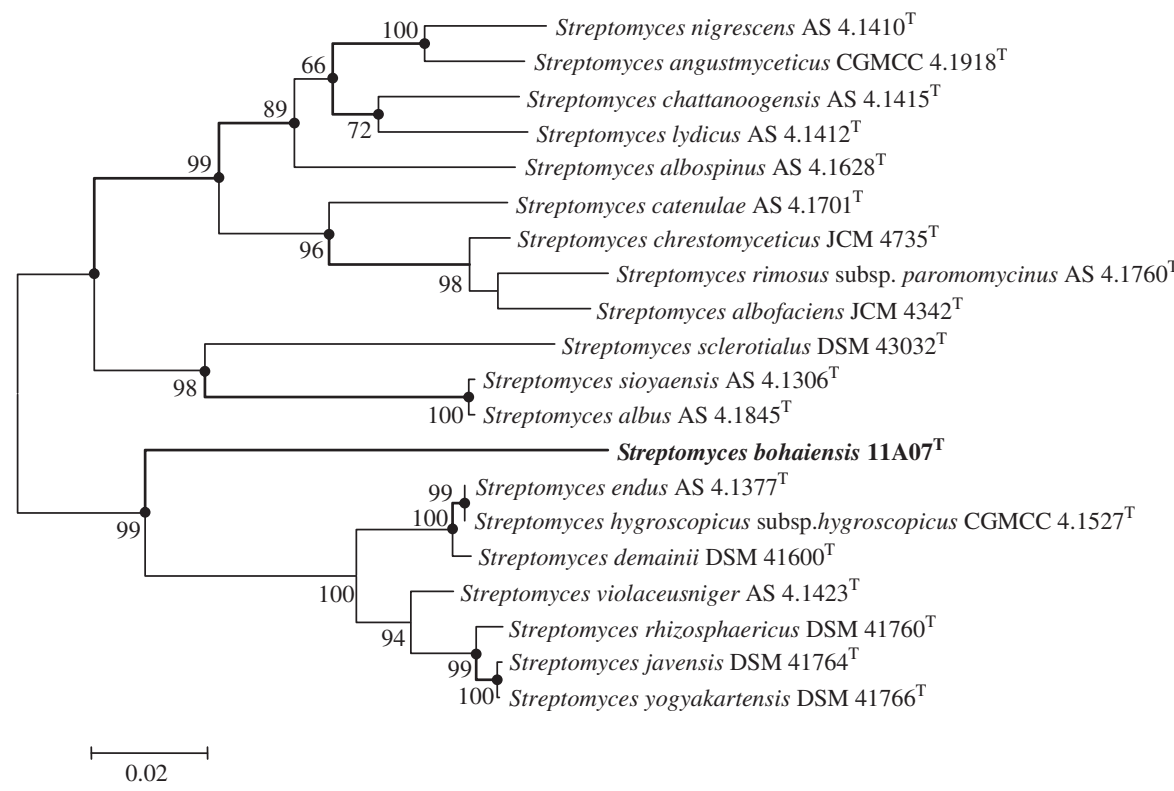

Figure 4 Maximum-likelihood phylogenetic tree based on five gene (atpD-gyrB-recA-rpoB-trpB) concatenated sequences showing the position of strain $11 \mathrm{A07}{ }^{\top}$ in the genus Strepomyces. Filled circles indicate branches that were also recovered using the maximum parsimony and neighbor-joining trees. Bootstrap values (expressed as percentages of 1000 replications) of above $50 \%$ are shown at the branch points. Bar, 0.02 sequence divergence.

diphosphatidylglycerol, phosphatidylethanolamine, phosphatidylinositol, phosphatidylinositol mannoside and an unknown phospholipid. The $\mathrm{G}+\mathrm{C}$ content of the genomic DNA is $71.4 \mathrm{~mol} \%$.

The type strain, $11 \mathrm{~A} 07^{\mathrm{T}}\left(=\mathrm{JCM} 19630^{\mathrm{T}}=\mathrm{CCTCC}\right.$ AA $2013020^{\mathrm{T}}=$ KCTC $29263^{\mathrm{T}}-$ ), was isolated from a young fish (S. niphonius) collected from the Bohai Sea of China $\left(39^{\circ} 20^{\prime} \mathrm{N}, 122^{\circ} 17^{\prime} \mathrm{E}\right)$.

\section{ACKNOWLEDGEMENTS}

This research was supported by the National Natural Science Foundation of China (No. 41006088 \& No. 312700040) and National High-tech R \& D Program of China (863 Program) (2012AA092104). W-J Li was also supported by Guangdong Province Higher Vocational Colleges \& Schools Pearl River Scholar Funded Scheme (2014).

1 Waksman, S. A. \& Henrici, A. T. The nomenclature and classification of the actinomycetes. J. Bacteriol. 46, 337-341 (1943).

2 Euzéby, J. LPSN: List of prokaryotic names with standing in nomenclature http://www. bacterio.cict.fr/s/streptomycesa.html (2013).

3 Bérdy, J. Bioactive microbial metabolites. J. Antibiot. 58, 1-26 (2005).

4 Goodfellow, M. \& Fiedler, H. A guide to successful bioprospecting: informed by actinobacterial systematics. Antonie Van Leeuwenhoek 98, 119-142 (2010).

5 Blunt, J. W., Copp, B. R., Keyzers, R. A., Munro, M. H. \& Prinsep, M. R. Marine natural products. Nat. Prod. Rep. 30, 237-323 (2013).

6 Blunt, J. W., Copp, B. R., Munro, M. H. G., Northcote, P. T. \& Prinsep, M. R. Marine natural products. Nat. Prod. Rep. 28, 196-268 (2011).

7 Williams, P. G. Panning for chemical gold: marine bacteria as a source of new therapeutics. Trends Biotechnol. 27, 45-52 (2009).

8 Lam, K. S. Discovery of novel metabolites from marine actinomycetes. Curr. Opin. Microbiol. 9, 245-251 (2006).

9 Pan, H.-Q. Research of new bioactive natural products from microorganisms by integration of biological and chemical methods Shenyang Pharmaceutical University, ShenYang (2013).

10 Kawato, M, Shinobu, R. On Streptomyces herbaricolor sp.nov. Supplement: a simple technique for the microscopic observation. Mem. Osaka Univ. Lib Arts Educ. B Nat. Sci. 8, 114-119 (1959).

11 Williams, S. \& Davies, F. Use of a scanning electron microscope for the examination of actinomycetes. J. Gen. Microbiol. 48, 171-177 (1967).

12 Shirling, E. B. \& Gottlieb, D. Methods for characterization of Streptomyces species. Int. J. Syst. Bacteriol. 16, 313-340 (1966).
$13 \mathrm{Xu}$, P. et al. Naxibacter alkalitolerans gen. nov., sp. nov., a novel member of the family 'Oxalobacteraceae'isolated from China. Int. J. Syst. Evol. Microbiol. 55, 1149-1153 (2005).

14 Tindall, B. J., Sikorski, J., Smibert, R. M. \& Krieg, N. R. in Methods for General and Molecular Microbiology, 3rd edn (eds Reddy, C. A. et al.) 330-393 (American Society for Microbiology: Washington DC, 2007).

15 Goodfellow, M. Numerical taxonomy of some nocardioform bacteria. J. Gen. Microbiol. 69, 33-80 (1971).

16 Athalye, M., Goodfellow, M., Lacey, J. \& White, R. Numerical classification of Actinomadura and Nocardiopsis. Int. J. Syst. Bacteriol. 35, 86-98 (1985)

17 Pridham, T. \& Gottlieb, D. The utilization of carbon compounds by some Actinomycetales as an aid for species determination. J. Bacteriol. 56, 107-114 (1948).

18 Sasser, M. Identification of bacteria by gas chromatography of cellular fatty acids. USFCC News/ 20, 1-6 (1990).

19 Staneck, J. L. \& Roberts, G. D. Simplified approach to identification of aerobic actinomycetes by thin-layer chromatography. Applied microbiology 28, 226-231 (1974).

20 Tang, S. K. et al. Zhihengliuella alba sp. nov., and emended description of the genus Zhihengliuella. Int. J. Syst. Evol. Microbiol. 59, 2025-2032 (2009).

21 Collins, M., Pirouz, T., Goodfellow, M. \& Minnikin, D. Distribution of menaquinones in actinomycetes and corynebacteria. J. Gen. Microbiol. 100, 221-230 (1977)

22 Tamaoka, J., Katayama-Fujimura, Y. \& Kuraishi, H. Analysis of bacterial menaquinone mixtures by high performance liquid chromatography. J. Appl. Microbiol. 54, 31-36 (1983).

23 Minnikin, D., Collins, M. \& Goodfellow, M. Fatty acid and polar lipid composition in the classification of Cellulomonas, Oerskovia and related taxa. J. Appl. Microbiol. 47, 87-95 (1979).

24 Collins, M. \& Jones, D. Lipids in the classification and identification of coryneform bacteria containing peptidoglycans based on 2,4-diaminobutyric acid. J. Appl. Microbiol. 48, 459-470 (1980).

25 Weisburg, W. G., Barns, S. M., Pelletier, D. A. \& Lane, D. J. 16 S ribosomal DNA amplification for phylogenetic study. J. Bacteriol. 173, 697-703 (1991).

$26 \mathrm{Kim}, 0 . \mathrm{S}$. et al. Introducing EzTaxon-e: a prokaryotic 16S rRNA gene sequence database with phylotypes that represent uncultured species. Int. J. Syst. Evol. Microbiol. 62, 716-721 (2012).

27 Guo, Y., Zheng, W., Rong, X. \& Huang, Y. A multilocus phylogeny of the Streptomyces griseus 16S rRNA gene clade: use of multilocus sequence analysis for streptomycete systematics. Int. J. Syst. Evol. Microbiol. 58, 149-159 (2008).

28 Thompson, J. D., Gibson, T. J., Plewniak, F., Jeanmougin, F. \& Higgins, D. G. The CLUSTAL_X windows interface: flexible strategies for multiple sequence alignment aided by quality analysis tools. Nucleic Acids Res. 25, 4876-4882 (1997).

29 Saitou, N. \& Nei, M. The neighbor-joining method: a new method for reconstructing phylogenetic trees. Mol. Biol. Evol. 4, 406-425 (1987).

30 Fitch, W. M. Toward defining the course of evolution: minimum change for a specific tree topology. Syst. Biol. 20, 406-416 (1971). 
31 Felsenstein, J. Evolutionary trees from DNA sequences: a maximum likelihood approach. J. Mol. Evol. 17, 368-376 (1981)

32 Tamura, K. et al. MEGA5: molecular evolutionary genetics analysis using maximum likelihood, evolutionary distance, and maximum parsimony methods. Mol. Biol. Evol. 28, 2731-2739 (2011).

33 Kimura, M. A simple method for estimating evolutionary rates of base substitutions through comparative studies of nucleotide sequences. J. Mol. Evol. 16 111-120 (1980)

34 Felsenstein, J. Confidence limits on phylogenies: an approach using the bootstrap. Evolution 39, 783-791 (1985).

35 Marmur, J. A procedure for the isolation of deoxyribonucleic acid from micro-organisms. J. Mol. Biol. 3, 208-218 (1961)

36 Mesbah, M., Premachandran, U. \& Whitman, W. B. Precise measurement of the $\mathrm{G}+\mathrm{C}$ content of deoxyribonucleic acid by high-performance liquid chromatography. Int J. Syst. Bacteriol. 39, 159-167 (1989).
37 Williams, S. et al. Numerical classification of Streptomyces and related genera. J. Gen Microbiol. 129, 1743-1813 (1983).

38 Stackebrandt, E. \& Ebers, J. Taxonomic parameters revisited: tarnished gold standards. Microbiol Today 33, 152-155 (2006)

39 Kim, M., Oh, H.-S., Park, S.-C. \& Chun, J. Towards a taxonomic coherence between average nucleotide identity and 16S rRNA gene sequence similarity for species demarcation of prokaryotes. Int. J. Syst. Evol. Microbiol. 64, 346-351 (2014).

40 Rong, X. \& Huang, Y. Taxonomic evaluation of the Streptomyces hygroscopicus clade using multilocus sequence analysis and DNA-DNA hybridization, validating the MLSA scheme for systematics of the whole genus. Syst. Appl. Microbiol. 35, 7-18 (2012)

$41 \mathrm{Cui}, \mathrm{Y}$. et al. Streptomyces panacagri sp. nov., isolated from soil of a ginseng field. Int J. Syst. Evol. Microbiol. 62, 780-785 (2012).

42 Li, W.-J. et al. Streptomyces sodiiphilus sp. nov., a novel alkaliphilic actinomycete. Int. J. Syst. Evol. Microbiol. 55, 1329-1333 (2005).

Supplementary Information accompanies the paper on The Journal of Antibiotics website (http://www.nature.com/ja) 